\title{
Measuring regional accessibility with public transport - case of Koroška region, Slovenia
}

\author{
Simon Koblar ${ }^{\text {a }}$ \\ a Urban Planning Institute of the Republic of Slovenia
}

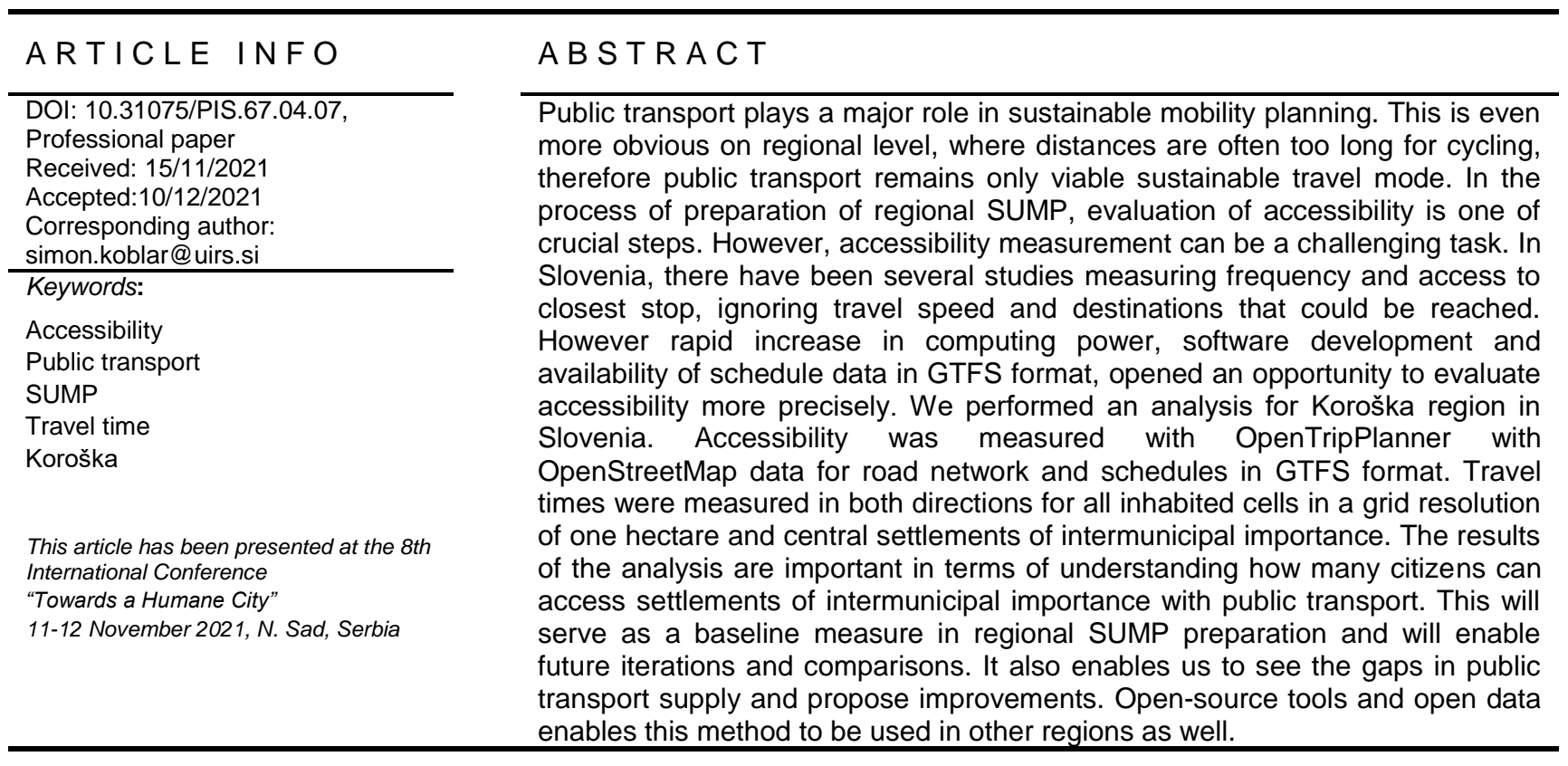

\section{Introduction}

Public transport is one of the key sustainable mobility modes, especially on longer distances. It also plays important part in preparation of regional SUMP. Important step in planning public transport networks is measurement of accessibility that current network provides. Different methods are used to measure accessibility [1], [2]. In Slovenia several studies measured infrastructure-based accessibility [3]-[7]. Disadvantage of these type of indicators is focus on accessibility from the origin to the public transit service, thus ignoring travel speed and reachable destinations [8]. To date, no study in Slovenia included public transport travel times in accessibility measurements. In the paper we present measurement of accessibility to settlements with at least intermunicipal importance by public transport, including access to transit station, in-vehicle time, potential transfer time and walking to destination.
We did not choose to weight different parts of travel time as did some studies [9], because we wanted a simple to understand indicator, that would be used as a baseline measurement in the process of SUMP preparation and communication with stakeholders.

\section{Methodology}

Paper focuses on measurement of accessibility with public transport to settlements of at least intermunicipal importance in Koroška region, Slovenia. Koroška had 70,253 inhabitants in year 2019 [10]. Northern part has a train connection, other parts are served with bus connections. Since settlements are small, there is no city public transit in the region. Settlements with at least intermunicipal importance were chosen because they provide enough public and private services [11]. In Koroška this are Dravograd and Ravne na Koroškem with intermunicipal importance and Slovenj Gradec with regional importance. 
Population data for year 2019 in one hectare grid was retrieved from Statistical office [12]. Public transport schedule data for intercity bus connections and trains in GTFS format for year 2019 was provided by Ministry of infrastructure. Pedestrian network was retrieved from OpenStreetMap [13]. Data preparation and maps were created in QGIS open-source GIS software. OpenTripPlanner [14] in combination with python script [15] was used to measure travel times. Aggregation and statistical analysis of the travel times was performed in Microsoft Access.

Travel times with public transport were measured in two directions between inhabited grid cells to 58 settlements in Slovenia with at least intermunicipal importance. Calculation for whole Slovenia was needed to enable comparison of accessibility in Koroška to national average. Total walking distance was limited to $2000 \mathrm{~m}$. Travel times to regional centres were calculated for departures between 6:00 and 8:00 and back from 14:00 and 16:00.

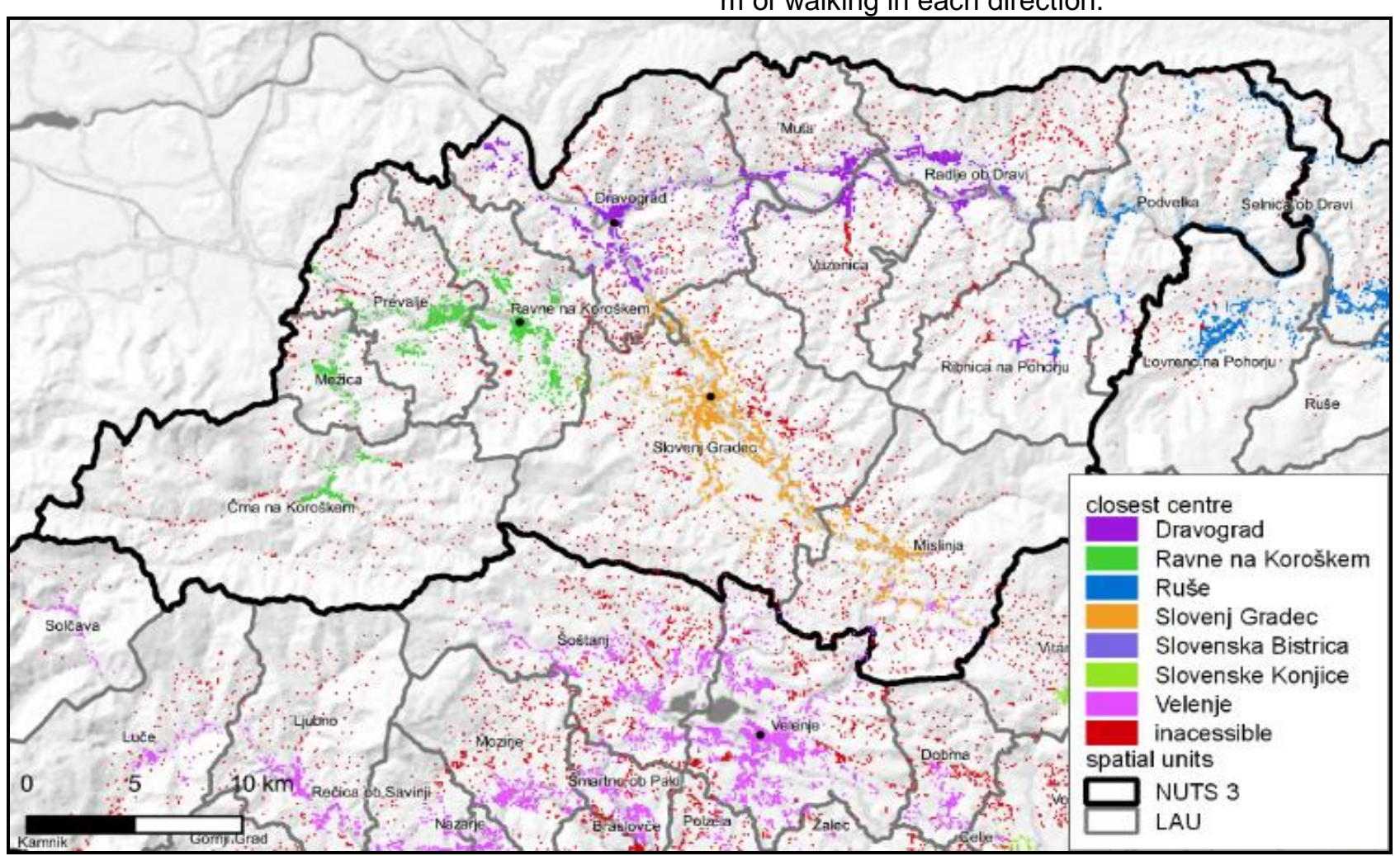

Figure 1. Catchment areas by public transport travel time

Source: OpenStreetMap contributors 2021, Surveying and Mapping Authority 2021

Public transport accessibility to regional centre (Slovenj Gradec) is shown in table 1. Only inhabitants of Koroška region are included. Table 2 shows travel times for inhabitants of Koroška region to three settlements in Koroška with at least intermunicipal importance - Slovenj Gradec, Dravograd and Ravne na Koroškem.
We wanted to represent best case scenario with flexible departure times and predicted that passengers would check timetable before arriving at the stop. Therefore, we calculated departures every 15 minutes and subtracted initial wait time. For each origindestination pair, shortest travel time for each direction was used to calculate average travel time. Calculation in both directions was needed, because in rural areas with low frequency, direct connection or connection with short transfer time is sometimes only available in one direction.

\section{Results}

In the process of SUMP preparation for Koroška region, travel times for Koroška region were analysed in detail. Some statistics were also calculated on a national level, which enabled us to put the result into the national context. Figure 1 shows catchment areas of settlements with intermunicipal importance. Red colours represent areas that are not accessible within 120 minutes of travel time or require more than 2000 $\mathrm{m}$ of walking in each direction. 
Table 2. Accessibility of Koroška residents to closest intermunicipal centre by public transport.

\begin{tabular}{|c|c|c|}
\hline travel time - minutes & inhabitants & $\begin{array}{c}\text { share of } \\
\text { inhabitants }\end{array}$ \\
\hline up to 45 & 53,836 & $77 \%$ \\
\hline $45-90$ & 4,206 & $6 \%$ \\
\hline $90-120$ & 192 & $0 \%$ \\
\hline more than 120 or inaccessible & 12,019 & $17 \%$ \\
\hline SUM & 70,253 & $100 \%$ \\
\hline
\end{tabular}

Source: own calculations

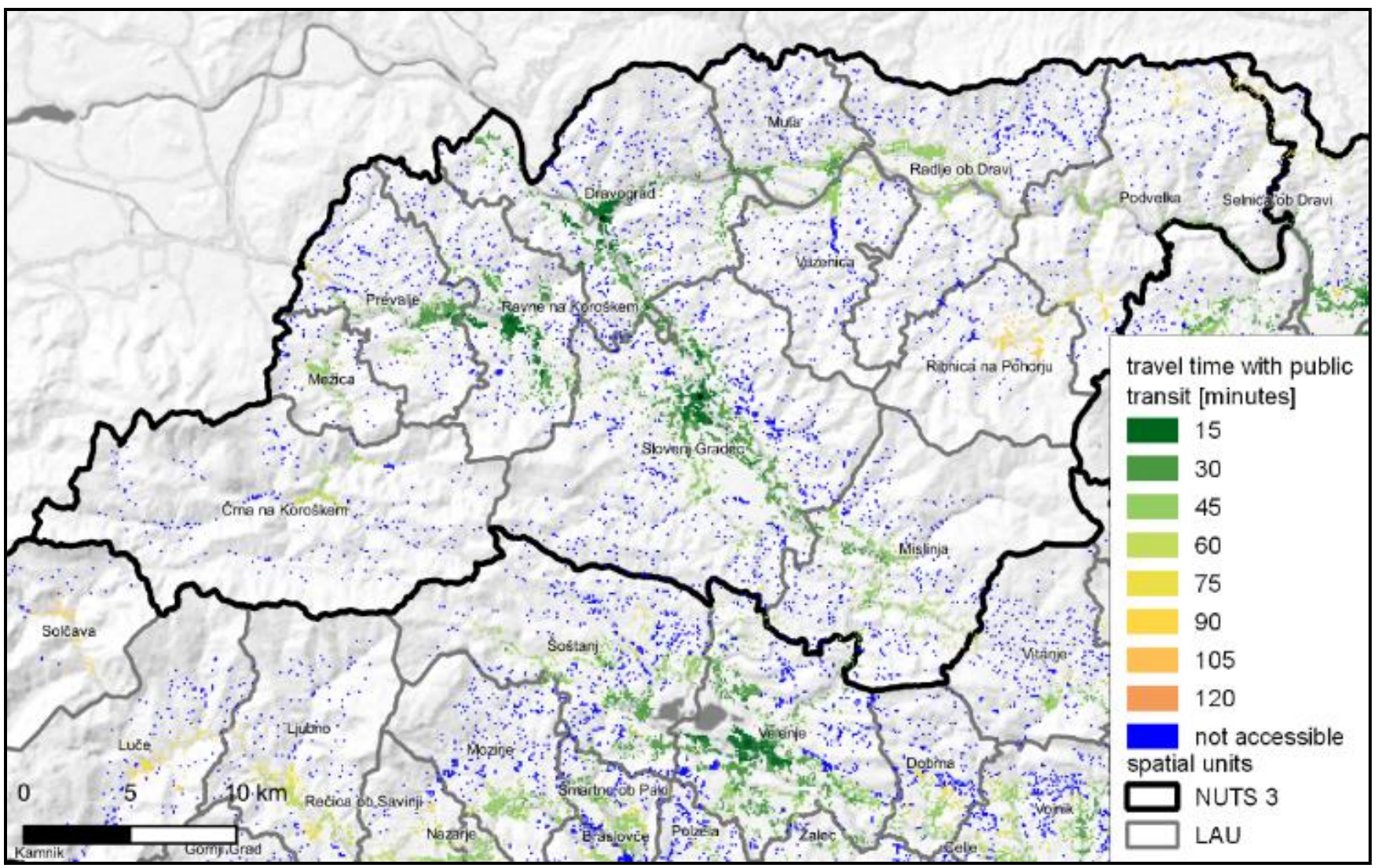

Figure 2. Travel times with public transport to cities with at least intermunicipal importance

Source: OpenStreetMap contributors 2021, Surveying and Mapping Authority 2021

\section{Discussion}

Slovenj Gradec as a regional center can be reached in 45 minutes by public transport by $43 \%$ of inhabitants of Koroška region, which is significantly lower than 77 $\%$ that can reach centers with at least intermunicipal importance. Nevertheless $80 \%$ of Koroška residents can reach Sovenj Gradec by public transport. For services that are not needed daily even a longer travel time is better than no public transport connections. For services needed daily, intermunicipal centers play a

major role. Spatial distribution of three intermunicipal centers is enabling public transport travel times under 45 minutes for $77 \%$ of inhabitants, compared to $81 \%$ on national level. Only $17 \%$ of inhabitants of Koroška region can't reach intermunicipal centers. Considering rugged terrain, accessibility to intermunicipal centres in Koroška is sufficient. All valleys and major settlements have public transport connections available. Areas
Figure 2 shows travel times for residents of Koroška with public transport to closest settlement with at least intermunicipal importance. Note that closest centre can be outside of Koroška region - see figure 1. outside of valleys are so sparsely populated, that it is not viable to provide a regular public transit. These areas could be served by on-demand service and/or integration of school bus lines to regular public transport as feeder lines to existing bus and train connections.

Public transport service areas are quite evenly distributed between Slovenj Gradec, Ravne na Koroškem and Dravograd - see figure 1. This enables lower travel times to closest center. Therefore, it is vitally important, that Dravograd and Ravne na Koroškem provide enough public services and amenities. Municipality of Podvelka in the eastern part of the region has better connections with Ruše, which is in Podravska region. This shows a discrepancy between traffic region and NUTS 3 region. Podvelka should therefore be included or at least considered in preparation of SUMP for Podravska region. 
Despite relatively good accessibility, there is still room for improvement. Especially with train connection, which is outdated and does not enable sufficient speeds. But train has a great potential, since it is independent of any traffic jams. Another opportunity is cross border connection to Bleiburg, Austria, where Koralm railway connecting Graz and Klagenfurt is under construction.

New infrastructure is also planned on Slovenian side, but in this case a new motorway between Velenje and Slovenj Gradec is being built. This provides opportunity to organize new express bus lines, but existing bus lines passing through settlements should remain active to maintain current accessibility level.

\section{Conclusion}

Measurement of public transport travel times proved to be useful and easy to understand indicator, which was used for the purpose of regional SUMP preparation. Results showed that residents of Koroška have a relatively good connectivity to regional centres, especially if we consider roughed terrain. However, this does not ensure high usage of public transport, since travel time with private car is still more competitive. Our use case is also not representative for whole population, since we measured public transport travel times only in a best-case scenario. Moreover, some services are not available close to the city centers, and therefore require more walking time. Opportunity for public transport improvements will be new expressway which is under construction at the time of writing. New express lines that would use newly bult expressway can reduce travel times for longer distance travel. However, travel times with public transport will still be slower than by car due to lover maximum allowed speed of busses. On the other hand, new express lines should not reduce level of service for residents living in settlements that are currently served by regional bus connections.

Proposed methodology could be also used in other regions since it relies on standardized GTFS data and OpenStreetMap data which is available world-wide. Calculations are done with open-source tool OpenTripPlanner. This shows that accessibility analyses don't have to be expensive and time consuming process.

\section{References}

[1] A. Malekzadeh and E. Chung, 'A review of transit accessibility models: Challenges in developing transit accessibility models', International Journal of Sustainable Transportation, vol. 14, no. 10, pp. 733-748, Aug. 2020, doi: 10.1080/15568318.2019.1625087.

[2] K. T. Geurs and B. van Wee, 'Accessibility evaluation of landuse and transport strategies: review and research directions', Journal of Transport Geography, vol. 12, no. 2, pp. 127-140, Jun. 2004, doi: 10.1016/j.jtrangeo.2003.10.005.

[3] M. Gabrovec and D. Bole, 'Dostopnost do avtobusnih postajališč', Geografski vestnik, vol. 78 , no. 2, pp. 39-51, 2006.

[4] J. Kozina, 'Modeliranje prostorske dostopnosti do postajališč javnega potniškega prometa v Ljubljani', Geografski vestnik, vol. 82, pp. 97-107, 2010.

[5] M. Gabrovec and N. Razpotnik Visković, 'Dostopnost do javnega potniškega prometa kot pogoj za socialno vključenost dijakov', Geografski vestnik, vol. 90, no. 2, pp. 109-120, 2018.

[6] J. Tiran, L. Mladenovič, and S. Koblar, 'Dostopnost do javnega potniškega prometa v Ljubljani po metodi PTAL', Geodetski vestnik, vol. 59, no. 4, pp. 723-735, 2015.

[7] A. Zavodnik Lamovšek, M. Čeh, and U. Košir, 'Analiza dostopnosti prebivalcev do javnih dejavnosti z medkrajevnim avtobusnim potniškim prometom', in Geografski informacijski sistemi v Sloveniji 2009-2010, D. Perko and D. Perko, Eds. Ljubljana: Založba ZRC, 2010, pp. 251-260. [Online]. Available: sazu.si/zalozba/catalog/view/649/2733/214-2

[8] S. Kaplan, D. Popoks, C. G. Prato, and A. (Avi) Ceder, 'Using connectivity for measuring equity in transit provision', Journal of Transport Geography, vol. 37, pp. 82-92, May 2014, doi: 10.1016/j.jtrangeo.2014.04.016.

[9] B. Tahmasbi and $H$. Haghshenas, 'Public transport accessibility measure based on weighted door to door travel time', Computers, Environment and Urban Systems, vol. 76, pp. 163-177, Jul. 2019, doi: 10.1016/j.compenvurbsys.2019.05.002.

[10]'SiStat', Statistical Office of the Republic of Slovenia, 2019. https://pxweb.stat.si/SiStat (accessed Mar. 18, 2020).

[11]J. Nared et al., 'Central settlements in Slovenia in 2016', Acta geographica Slovenica, vol. 57, no. 2, Art. no. 2, Jan. 2017, doi: 10.3986/AGS.4606.

[12]'SURS STAGE', SURS STAGE, 2019. https://gis.stat.si/ (accessed Aug. 26, 2019).

[13]'OpenStreetMap', $\quad$ OpenStreetMap, 2021. https://www.openstreetmap.org/copyright (accessed Sep. 15, 2021).

[14]'OpenTripPlanner'. https://www.opentripplanner.org/ (accessed Aug. 05, 2019).

[15]R. H. M. Pereira and L. Grégoire, Tutorial with reproducible example to estimate a travel time matrix using OpenTripPlanner and Python. 2019. doi: 10.5281/ZENODO.3242134. 